\title{
Soybean production in 2025 and 2050 in the southeastern USA based on the SimCLIM and the CSM-CROPGRO-Soybean models
}

\author{
Yawen Bao ${ }^{1}$, Gerrit Hoogenboom ${ }^{1,2, *}$, Ron McClendon ${ }^{1}$, Peter Urich ${ }^{3}$ \\ ${ }^{1}$ College of Engineering, The University of Georgia, Athens, Georgia 30602, USA \\ ${ }^{2}$ AgWeatherNet Program, Washington State University, Prosser, Washington 99350-8694, USA \\ ${ }^{3}$ CLIMsystems, Flagstaff, Hamilton 3210, New Zealand
}

\begin{abstract}
This study developed an approach to determine the potential impact of climate change on soybean yield for 2025 and 2050 projections by combining the statistical downscaling model SimCLIM with the crop simulation model CSM-CROPGRO-Soybean. SimCLIM is an integrated assessment model (IAM) which can provide site-specific projections by using statistical downscaling based on 21 general circulation models (GCMs) and 6 greenhouse gas emission scenarios. The response of rainfed and irrigated soybean growth and yield to climate patterns based on $3 \mathrm{GCMs}$ and 6 emission scenarios was investigated. Tifton, Georgia, USA $\left(31.48^{\circ} \mathrm{N}, 83.53^{\circ} \mathrm{W}\right)$ was selected as an example location. The increase in temperature caused the number of days to maturity to decrease by $1.8 \mathrm{~d}$ for 2025 and by $2.3 \mathrm{~d}$ for 2050 compared to the reference years for both rainfed and irrigated conditions; however, later planted soybean showed a lower decrease. Increases in precipitation during the soybean growing season and in $\mathrm{CO}_{2}$ concentration led to projected yield increases of 6 to $22 \%$ for 2025 and 8 to $35 \%$ for 2050 for rainfed conditions. Projected increases for irrigated soybean yield were about 1 to $12 \%$ less than for rainfed soya. Generally, Tifton is suitable for both rainfed and irrigated soybean planting based on projections by the 3 GCMs. Farmers might have to shift the planting date to after June 5 to avoid potential heat stress. The cultivars that are suitable for rainfed conditions include AG6702 and S80-P2, while DP5634RR, DP5915RR, and AG6702 are more suitable for irrigated conditions.
\end{abstract}

KEY WORDS: Phenology · Grain yield · General Circulation Model · DSSAT · Rainfed · Irrigated · Climate change

Resale or republication not permitted without written consent of the publisher

\section{INTRODUCTION}

Soybean is a major crop in the southeastern USA in terms of acreage, production, and export. Numerous scientific studies indicate that the climate is changing (Alley et al. 2003, IPCC 2007, 2013, Trenberth 2011) and agriculture is vulnerable to the expected change in future climate conditions (Rosenzweig et al. 2007, Ainsworth \& Ort 2010, Sakurai et al. 2011). Several studies have been conducted to determine the vulnerability of soybean production to climate change, including in the southeastern USA where agriculture is a dominant economic sector. Those projections were analyzed by coupling projections of general circulation models (GCMs) or regional climate models (RCMs) with the cropping system model CSMCROPGRO-Soybean model and earlier versions of this model. Curry et al. (1995) used climate models developed by the Goddard Institute for Space Studies (GISS), the Geophysical Fluid Dynamics Laboratory (GFDL), and the United Kingdom Meteorological Office (UKMO) to evaluate rainfed and irrigated soybean production under future climate change. Alexandrov \& Hoogenboom (2000) assessed the vulnerability and adaptation of agricultural crops under climate change projections based on 12 GCMs. 
Mearns et al. (2003) examined the performance of the Commonwealth Scientific and Industrial Research Organisation (CSIRO) model, a GCM, and the RCM RegCM2, and then applied those 2 climate models for projecting soybean production (Carbone et al. 2003). All these studies were conducted based on 2 assumed gas emission scenarios, a control scenario in which the $\mathrm{CO}_{2}$ concentration does not change, and a scenario with elevated $\mathrm{CO}_{2}$ concentration.

Although these studies addressed the potential effects of climate change on soybean production, they had 3 limitations. The first limitation was the mismatch in spatial scale between the outputs of climate models and the inputs required for crop models. These studies assumed that the large grid of a GCM or RCM was uniform and the simulations from a crop model for one location could represent the entire grid. However, it has been widely recognized that the GCMs were not designed to make projections at a regional scale (Carbone et al. 2003, Christensen et al. 2007), while the spatial resolution of RCMs such as the RegCM2 at $50 \times 50 \mathrm{~km}$ is more appropriate (Mearns et al. 2003). Mearns et al. (2003) examined the performance of the GCMs and RCMs by comparing their present-day projections with global or regional scale aggregations of observed weather data (Rivington et al. 2008). They found that the CSIRO and RegCM2 models generated different projections for the southeastern USA. Impact studies for the southeastern USA also showed that projections from climate models with different spatial scales could affect predictions for crop production. (Carbone et al. 2003, Doherty et al. 2003, Tsvetsinskaya et al. 2003). Since the uncertainty introduced into system model estimates due to weather data sources can be significant (Rivington et al. 2006), it is important to develop future climate projections for a specific location that match the local input requirements for crop simulation models.

The second limitation affecting most of the previous studies was the narrow range future climate patterns represented: the assumption was that the $\mathrm{CO}_{2}$ concentration would either not change or would double in the future. However, the scenarios that cover a wide range of values for the main driving forces for the future gas emissions, ranging from demographic to technological and economic developments, are provided by the Special Report on Emissions Scenarios (SRES) (Nakicenovic \& Swart, 2000) and were used for the Fourth Assessment Report (AR4) of Intergovernmental Panel on Climate Change (IPCC). The third limitation was that none of these previous studies provided sufficient rationale for the selection of the GCMs for the regional climate change studies.

The overall goal of this study was to develop an approach to predict the effects of climate change on soybean production for a specific location in the southeastern USA. The objectives were (1) to select appropriate GCMs for projection of the future climate patterns for Tifton $\left(31.48^{\circ} \mathrm{N}, 83.53^{\circ} \mathrm{W}\right)$, Georgia, (2) to determine the impact of climate change on soybean production for projections for 2025 and 2050, and (3) to evaluate alternate crop management options for adaptation.

\section{METHODOLOGY}

\subsection{Climate model}

SimCLIM is an integrated assessment model (IAM) that was originally developed to enable integrated assessments of the effects of climate change on New Zealand's environment (Kenny et al. 1995). A bilinear interpolation (R. Warrick pers. comm.) was applied by SimCLIM to downscale the outputs of 21 GCMs (see Table S1 in the Supplement at www.intres.com/articles/suppl/c063p073_supp.pdf) to national, regional, local, and site-specific scales for many countries across the world, including the USA. The highest resolution for the spatial scales is $1 \times 1 \mathrm{~km}$. The baseline data for SimCLIM span the period from 1961 to 1990. The climate projections for different spatial scales can be generated from 1991 to 2100. The effects of gas emissions are analyzed using the IPCC Special Report on Emissions Scenarios (SRES) greenhouse gas emissions scenarios A1B, A1FI, A1T, A2, B1, and B2 as inputs for SimCLIM. The sitespecific scale of SimCLIM was designed to address questions relating to smaller-scale effects of climate change on agricultural and climatological risk (Kenny et al. 2001a). This has the important benefit of allowing the user to match space and time scales between outputs from GCMs and input requirements for impact assessments such as crop models (Semenov \& Barrow 1997).

SimCLIM has been used to assist in climate impact studies for various sectors including water supply (Warrick 2007), agriculture (Kenny et al. 2000, 2001b), ecosystems (Storey 2009), and coastal zones (Abuodha 2009). Specific potential effects of climate change on fruit phenology and production (Austin \& Hall 2001, Hall et al. 2001), crop production (Jamieson \& Cloughley 2001), pasture management (Clark et al. 2001), soil and land systems (Parshotam \& Tate 2001), regional resources (Kenny et al. 2001c), and sea-level 
rise (Warrick et al. 2005) were determined for New Zealand. SimCLIM has also been coupled with several impact models for horticultural and arable crops, as well as for pasture production (Warrick et al. 1996, Warrick 2009).

\subsection{Climate model selection}

To be able to apply future climate projections to regional or local impact studies, the appropriate GCM should first be selected (Coquard et al. 2004, Brekke et al. 2008, Pierce et al. 2009). Use of a single GCM restricts the projections to a narrow range; however, the number of GCMs that can be used is limited by resource constraints (Hulme et al. 2000). For this study, 3 GCMs were selected based on the following criteria.

A widely accepted assumption for the evaluation of the accuracy of climate models is that if a climate model can predict the current climate accurately, it will also provide accurate predictions for future climate projections (Coquard et al. 2004). The selection of a GCM for regional climate change studies is also often based on the quality of the simulated regional climate (Pierce et al. 2009). Thus the first criterion was to select the GCM with projections closest to the observed historical weather data for the study location. The use of an average of multiple models to calculate projections was adopted by IPCC for their AR4 (Meehl et al. 2007). This also has been a common approach for applying the output of GCMs to impact studies (Seager et al. 2007, Pierce et al. 2009). Thus the second criterion was to select the GCM with projections closest to the average of the 21 GCM projections (Table S1 in the Supplement). The third criterion was to select the GGM that has been used most frequently in impact studies based on SimCLIM. This was the UKMO-HadCM3 GCM (hereafter 'UKMO') (Kenny et al. 2001a, Warrick 2007).

Climate model selection was performed by examining localized projections from SimCLIM based on 21 GCMs. The projections of monthly precipitation and mean temperature from SimCLIM for the period 1991 to 2008 for Tifton were compared with observed data to select the first GCM. A single SRES scenario (A1B) was used for the GCM selection because it has been used frequently for agricultural impact studies (Backlund et al. 2008). Daily observed precipitation, maximum temperature, and minimum temperature for Tifton for the same period (1991-2008) were obtained from the National Climatic Data Center (NCDC) (Garcia y Garcia \& Hoogenboom 2005). Since all projected climate data were provided as monthly values for each year from 1991 to 2008, the monthly total precipitation and monthly average for mean temperature were calculated for the observed data for each year. Total monthly precipitation was the sum of the daily precipitation of a month, and average mean temperature was the mean of daily maximum and minimum temperatures for a 1 mo period.

The projected climate data were compared to the observed monthly data to determine the accuracy of SimCLIM in reproducing the present-day climate from 1991 to 2008. Two methods were applied to test the differences between the projected and observed monthly precipitation and mean temperature. The first method was the 2-tail Kolmogorov-Smirnov (KS) test with a $95 \%$ confidence level. The second method was to calculate the deviation from observed data for each of the $21 \mathrm{GCMs}$. In order to conduct the KS test, the $18 \mathrm{yr}$ average (1991-2008) of the monthly precipitation and mean temperature were calculated for projected data from each of the $21 \mathrm{GCMs}$ and compared with the observed data. For example, the average monthly precipitation in January was the average of monthly precipitation based on $18 \mathrm{yr}$ from 1991 to 2008. Finally, the deviation of each GCM from the average of 21 GCMs was calculated to select the second GCM.

\subsection{Soybean yield prediction}

The CSM-CROPGRO-Soybean model simulates the plant and soil carbon, water, and nitrogen balances for soybean (Hoogenboom et al. 1992, Jones et al. 2003) based on crop genetics, including cultivar-specific parameters or cultivar coefficients, and is one of the crop models included in the Decision Support System for Agrotechnology Transfer (DSSAT) (Jones et al. 2003, Hoogenboom et al. 2004). The CSM-CROPGRO-Soybean model has been evaluated extensively for predicting yield and response to genetic traits and management inputs in the southeastern USA (Mavromatis et al. 2001, 2002, Nijbroek et al. 2003, Garcia y Garcia et al. 2010). DSSAT Version 4.5.0.2 (Hoogenboom et al. 2011) was used in this study to simulate growth, development and yield under both rainfed and irrigated conditions for the reference years and for the 2025 and 2050 climate change projections. The years 2025 and 2050 were selected because many natural resources, planning and management activities already use time scales of 25 to $50 \mathrm{yr}$ for long-term investment planning and climate change projections for the next few decades are relatively certain (Hatfield et al. 2008).

Initial conditions, soil data, crop management, and weather data are the minimum input requirements 
for crop model operations (Hunt \& Boote 1998, Hoogenboom et al. 2012). Initial conditions have a large impact on early soybean growth and development. For initial conditions, the previous crop was defined as soybean; crop initial residue was $1000 \mathrm{~kg}$ $\mathrm{ha}^{-1}$ with a nitrogen concentration of $0.8 \%$ incorporated at a depth of $15 \mathrm{~cm}$, while root residue was $100 \mathrm{~kg} \mathrm{ha}^{-1}$. The local soil profile data was defined as a Tifton sandy loam (fine-loamy, siliceous, thermic Plinthic Paleudult), which is a common soil in the coastal plains of Georgia (Perkins et al. 1986). Crop management was set to a plant population at seeding and emergence of 34 plants $\mathrm{m}^{-2}$, a row spacing of $76 \mathrm{~cm}$, and a planting depth of $5 \mathrm{~cm}$ based on the soybean performance tests from the University of Georgia (UGA) College of Agricultural \& Environmental Science (CAES) Statewide Variety Testing (SWVT) program (Day et al. 2008). For irrigation management, the automatic irrigation option was used based on a management depth of $30 \mathrm{~cm}$ and a threshold of $50 \%$ of available soil moisture (Salazar et al. 2012).

The weather inputs for the DSSAT crop simulation models include daily precipitation, maximum and minimum temperature, and solar radiation. The longterm historical weather data for the period 1923 to 2008 were obtained from NCDC. However, this data set only includes precipitation and maximum and minimum temperatures. Therefore, the modified Weather Generator for Solar Radiation (WGENR) was used to generate the solar radiation based on a multivariate stochastic process using maximum and minimum temperature and precipitation as inputs (Garcia y Garcia \& Hoogenboom 2005, Garcia y Garcia et al. 2008).

SimCLIM can only provide climate data as monthly values, but daily data are required as inputs for a dynamic crop simulation model. In this study, the changes between projected and baseline climate data were applied to modify reference daily observed data and to get the daily data for 2025 and 2050 projections. For instance, the daily data for 2025 projections were obtained as follows. First, the changes between projection and the baseline (1961-1990), were calculated for monthly precipitation and mean temperature. Then the changes in precipitation and mean temperature were either multiplied or added to climate data for the reference period i.e. (19232008), using Environmental Modifications, a routine in the DSSAT file management structure. The obtained climate data were the 2025 projections. A total of 18 projections were obtained based on the 3 selected GCMs and 6 standard SRES scenarios, i.e. A1B, A1FI, A1T, A2, B1, and B2, for both the 2025 and 2050 projections, as follows:

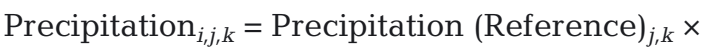

$$
\left(1+\Delta \text { Precipitation }_{i, j}\right)
$$

where $i$ is 2025 or 2050, $j$ is the month of a year from 1 to $12, k$ is day of a month from 1 to 28 or 29 for February, 1 to 30 for April, June, September, and November, and 1 to 31 for the remaining months of a year, and $\Delta$ Precipitation $_{i, j}$ is the percentage change in monthly precipitation for 2025 or 2050 compared to the baseline. The reference weather data spanned the period from 1923 to 2008 as discussed previously.

Eqs (2) and (3) below describe the changes for the daily maximum and minimum temperature for 2025 and 2050, respectively:

Max Temperature Ti,j,k $_{1}=$ Max Temperature (reference) ${ }_{j, k}$

$$
+\Delta \text { Mean Temperature } e_{i, j}
$$

Min Temperature ${ }_{i, j, k}=$ Min Temperature (reference) $)_{j, k}$ $+\Delta$ Mean Temperature ${ }_{i, j}$

where $i$ is the change in monthly mean temperature for 2025 or 2050 from the baseline. It was assumed that the daily change in precipitation and temperature was the same for an entire 1 mo period. Since the reference years contained 86 different growing seasons, the daily weather data for the 2025 and 2050 projections also included 86 different growing seasons to account for the inherent annual weather variability.

Because the $\mathrm{CO}_{2}$ concentration affects soybean growth and yield significantly (Ainsworth et al. 2002), the increase in $\mathrm{CO}_{2}$ concentration (Table $\mathrm{S} 2$ in the Supplement) was considered for simulating soybean yield for 2025 and 2050 projections.

Four planting dates (May 5, May 15, May 25, and June 5) and 6 cultivars (DP5634RR, DP5915RR, AG6702, AGS758RR, DP7220RR, and S80-P2) were selected for analyzing the effects of climate change. The genetic coefficients for the 6 cultivars were obtained from a previous study (Bao et al. 2015) as shown in Table 1. For the final analysis, the number of days to maturity and grain yield were determined for the reference years and for 2025 and 2050 projections. Possible adaptation strategies were identified for potential soybean planting at Tifton for 2025 and 2050 projections based on the impact analysis component of this study.

\section{RESULTS}

\subsection{Climate model selection}

In order to select the GCM that most closely represented the observed data, the differences of projected monthly precipitation and mean temperature 
Table 1. Maturity group and genetic coefficients for the 6 cultivars used to study the effects of climate change on soybean production in southeastern USA. EMFL: time between plant emergence and flower appearance (photothermal day, hereafter 'd'); FLSH: time between first flower and first pod (d); FLSD: time between first flower and first seed (d); SDPM: time between first seed and physiological maturity (d); LFMAX: maximum leaf photosynthesis rate at $30^{\circ} \mathrm{C}, 350 \mathrm{ppm} \mathrm{CO}_{2}$, and high light ( $\mathrm{mg} \mathrm{CO} \mathrm{CO}^{-2} \mathrm{~s}^{-1}$ ); WTPSD: maximum weight per seed (g); SFDUR: seed filling duration for pod cohort at standard growth conditions (d); SDPDV: average number of seeds per pod under standard growing conditions; PODUR: time required for cultivar to reach final pod load under optimal conditions (d)

\begin{tabular}{|c|c|c|c|c|c|c|c|c|c|c|}
\hline Maturity group & Cultivar & EMFL & FLSH & FLSD & SDPM & LFMAX & WTPSD & SFDUR & SDPDV & PODUR \\
\hline \multirow[t]{2}{*}{ MG V } & DP5634RR & 22.88 & 12.32 & 23.87 & 34.9 & 0.8641 & 0.1895 & 25.95 & 2.045 & 12.49 \\
\hline & DP5915RR & 24.17 & 14.51 & 28.12 & 33.57 & 1.076 & 0.1895 & 22.73 & 2.045 & 12.49 \\
\hline MG VI & AG6702 & 24.29 & 15.61 & 27.76 & 36.83 & 0.9259 & 0.1895 & 25.96 & 2.045 & 12.49 \\
\hline \multirow[t]{2}{*}{ MG VII } & AGS758RR & 23.5 & 12.32 & 19.71 & 38.45 & 0.825 & 0.1701 & 20.01 & 2.045 & 10.69 \\
\hline & DP7220RR & 23.54 & 12.18 & 19.49 & 36.63 & 0.825 & 0.1701 & 20 & 2.045 & 7.505 \\
\hline MG VIII & S80-P2 & 21.33 & 9.8 & 15.68 & 38.31 & 0.825 & 0.1898 & 25.98 & 2.433 & 10.05 \\
\hline
\end{tabular}

for each GCM from the observed data during 1991 to 2008 were analyzed based on the KS test. The projected monthly precipitation from the 21 GCMs was not significantly different from observed at a $95 \%$ confidence level except for IPSL-CM4 and ECHAM5/ MPI-OM (Table S1 in the Supplement). The maximum difference between projected and observed precipitation using the $D$-values of the KS test ranged from 0.0645 for GISS-EH (hereafter GISS) to 0.2473 for ECHAM5/MPI-OM. The projected monthly mean temperature from the $21 \mathrm{GCMs}$ was not significantly different from the observed temperature at a $95 \%$ confidence level (Table S1). The $D$-value was 0.0556 for all GCMs, while 0.1111 for IPSL-CM4. The projections for monthly precipitation and mean temperature based on GISS were considered to be the closest to the observed data since the $D$-values for this GCM were the smallest.

The second criterion used to select the GCM that best represented the observed data was the difference of the monthly precipitation and mean temperature projections from the observed data during 1991 to 2008. It was assumed that the GCM with a deviation that was closest to 0 would represent the observed data the best. However, there was no clear difference among the $21 \mathrm{GCMs}$, especially for monthly precipitation (Fig. S1 in the Supplement at www.intres.com/articles/suppl/c063p073_supp.pdf). The deviations for monthly precipitation for GISS, which was selected based on the KS test discussed previously, were $22 \mathrm{~mm}$ for April, $42 \mathrm{~mm}$ for May, from 10 to $19 \mathrm{~mm}$ for February, March, June, August, September, October, and December, and $<6 \mathrm{~mm}$ for the remaining months of the year.

In general, the deviation of the projected monthly mean temperature for the 21 GCMs from the observed data for 1991 to 2008 ranged from -0.45 to $0.83^{\circ} \mathrm{C}$, but UKMO showed a difference of $2.2^{\circ} \mathrm{C}$ for
January (Fig. S2). Temperature differences for GISS, which was selected based on the KS test, were $0.65^{\circ} \mathrm{C}$ for April, from 0.1 to $0.3^{\circ} \mathrm{C}$ for June, July, November, and December, and $<0.09^{\circ} \mathrm{C}$ for the remaining months.

The difference of the monthly precipitation and mean temperature for each of the $21 \mathrm{GCMs}$ from the average of the 21 GCMs was the criterion for selecting the second GCM. The GCM with the smallest differences for the 12 months was selected. The GCMs whose monthly precipitation values differed least with from the average (by $<1 \mathrm{~mm}$ for most of the 12 months) were CSIRO-Mk3.5, MRI-CGCM2.3.2 (hereafter MRI), PCM, and UKMO (Fig. S3). The smallest differences in monthly mean temperature from the average $\left(<0.1^{\circ} \mathrm{C}\right.$ for most of the 12 months $)$ were found for MRIOC3.2 (hi-res), ECHAM5/MPI-OM and MRI (Fig. S4). Based on this analysis, MRI was selected as having the smallest difference for both monthly total precipitation and mean temperature.

\subsection{Climate projections for 2025 and 2050}

The projections for monthly precipitation (Fig. 1) and mean temperature (Fig. 2) for 2025 and 2050 were generated with SimCLIM based on the previously selected 3 GCMs, i.e. GISS), MRI, and UKMO and the 6 SRES scenarios A1B, A1FI, A1T, A2, B1, and B2.

The projections of GISS for precipitation varied by month, year, and climate change scenario for both the 2025 and 2050 projections (Fig. 1). In general, the trend for the change in precipitation for 2050 was similar for a given month compared to change for the same month for 2025, but with a larger change for 2050. For example, projected precipitation based on GISS decreased in January for both 2025 and 2050, but with a larger decrease in 2050. Among the 6 scenarios, the precipitation projections for 2025 based on 

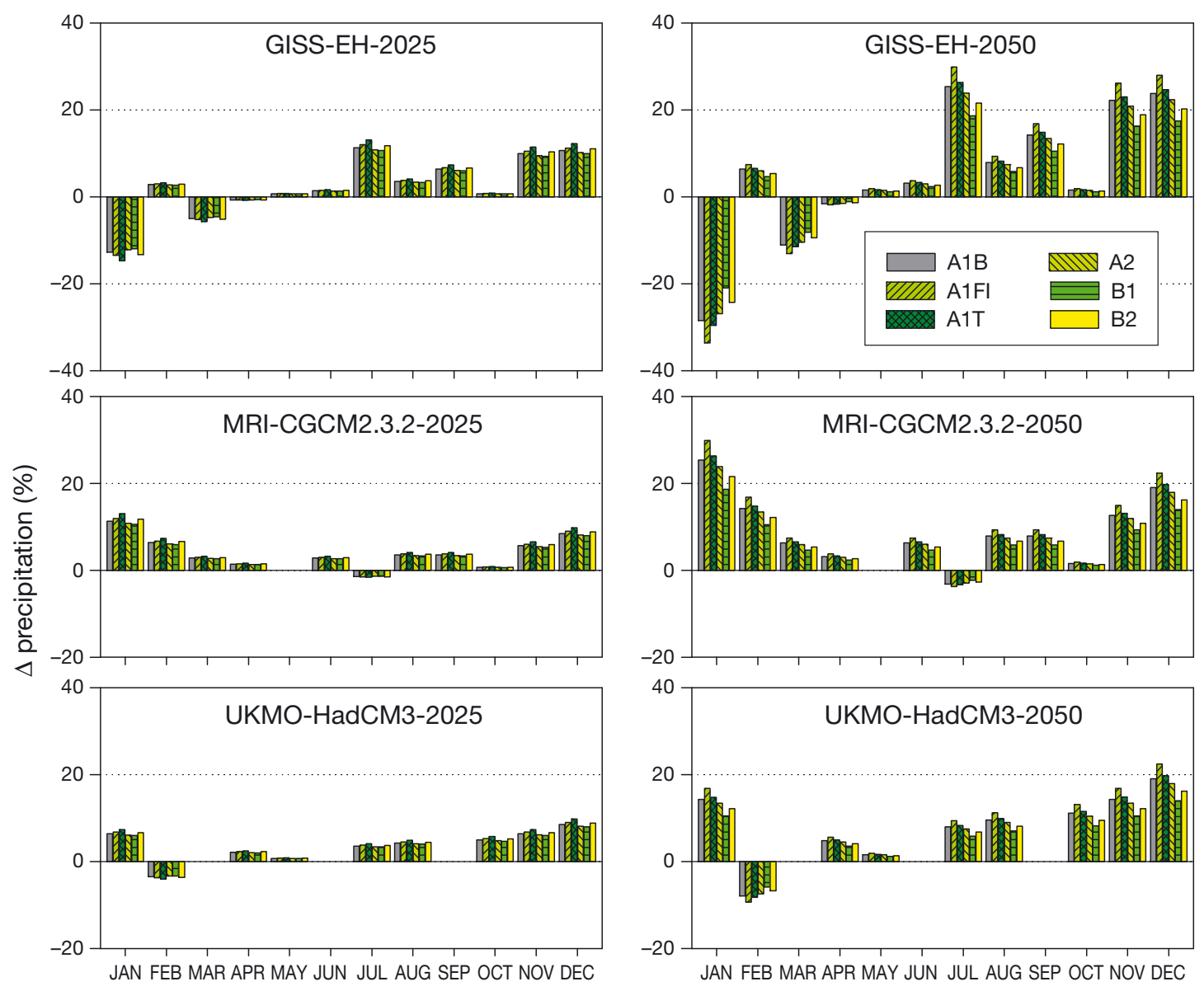

Fig. 1. Change (\%) in monthly precipitation in the study area (southeastern USA) projected for 2025 and 2050 by 3 selected global climate models (GCMs), i.e. GISS-EH, MRI-CGCM2.3.2, and UKMO-HadCM3, compared to the baseline (1961-1990)

the A1T scenario changed the most, followed by B2 and A1FI, and then A1B, A2, and B1. For 2050, the change in precipitation was the highest based on the A1FI scenario, followed by A1T and A1B, and then $\mathrm{A} 2$ and $\mathrm{B} 2$, and smallest change for B1. The differences among scenarios were larger for 2050 than for 2025. The GISS projections of precipitation for 2025 showed a decrease compared to the baseline of -12 to $-15 \%$ for January, -5 to $-6 \%$ for March, and $-1 \%$ for April. By contrast, precipitation for 2025 was projected to increase by 1 to $4 \%$ for February, May, June, August, and October and by 10 to $13 \%$ for July, September, November, and December for 2025. The differences among scenarios were no more than $3 \%$ for 2025. The GISS projections of changes in precipitation from the baseline for 2050 ranged from -21 to $-34 \%$ for January, $-11 \%$ for March, $-2 \%$ for April, 1 to $10 \%$ for February, May, June, August, and October, and 16 to $30 \%$ for the remaining months. The differences among scenarios were approximately $14 \%$ for 2050.
MRI projections of changes in precipitation differed from those of GISS (Fig. 1). For MRI, projected changes in precipitation changes were around $-1.4 \%-3 \%$ for July for 2025 and 2050 respectively. The changes in precipitation for March, April, June, August, September, and October ranged from 1 to $4 \%$ for 2025 and from 1 to $10 \%$ for 2050 ; while changes for January, February, November, and December ranged from 5 to $12 \%$ for 2025 and from 10 to $30 \%$ for 2050 . There was no change for May for either 2025 and 2050. The differences among scenarios were approximately $3 \%$ for 2025 and $11 \%$ for 2050 .

Compared with GISS and MRI, the changes in precipitation based on UKMO were smaller (Fig. 1). The changes in precipitation for February were $-4 \%$ for 2025 and ranged from -6 to $-10 \%$ for 2050 . Precipitation did not change for March, June, and September for 2025 and 2050, while for the remaining months differences ranged from 1 to $10 \%$ for 2025 and from 1 to $23 \%$ for 2050 . The differences among scenarios were $1 \%$ for 2025 and $6 \%$ for 2050 . 

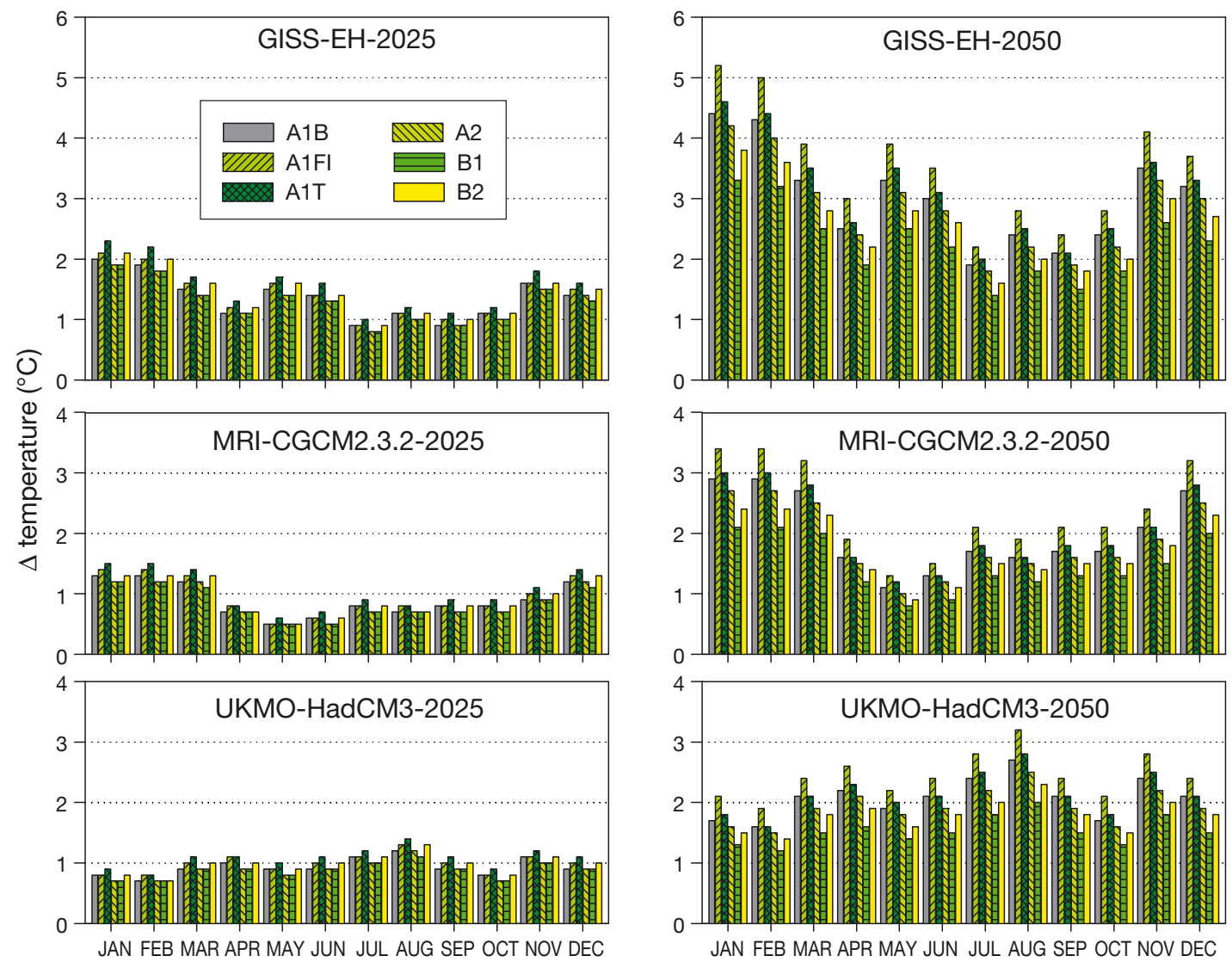

Fig. 2. Change $\left({ }^{\circ} \mathrm{C}\right.$ ) in monthly mean temperature in the study area (southeastern USA) projected for 2025 and 2050 by 3 selected global climate models (GCMs), i.e. GISS-EH, MRI-CGCM2.3.2, and UKMO-HadCM3, compared to the baseline (1961-1990)

The change in monthly mean temperature for 2025 and 2050 also varied by month, year, GCM, and scenario. However, the monthly mean temperature increased for all 12 months for both 2025 and 2050 projections (Fig. 2). In general, the increase in monthly mean temperature was, as expected, larger for 2050 than for 2025. The increase in temperature based on GISS was the largest, followed by UKMO, and then MRI. Among the 6 scenarios, the monthly mean temperature projection for 2025 based on the A1T scenario increased most, followed by B2 and $\mathrm{A} 1 \mathrm{FI}$, and then the A1B, A2, and B1 scenarios. For 2050 , the largest change in monthly mean temperature was based on the A1FI scenario, followed by $\mathrm{A} 1 \mathrm{~T}$ and $\mathrm{A} 1 \mathrm{~B}$, and then the $\mathrm{A} 2$ and $\mathrm{B} 2$ scenarios, while the smallest change was found for the B1 scenario. The differences among scenarios were larger for 2050 than for 2025. The increase in the monthly mean temperature ranged from 1 to $2^{\circ} \mathrm{C}$ for 2025 and from 2 to $5^{\circ} \mathrm{C}$ for 2050 based on GISS; from 0.5 to $1.5^{\circ} \mathrm{C}$ for 2025 and from 0.8 to $3^{\circ} \mathrm{C}$ for 2050 based on $\mathrm{MRI}$; and from 0.7 to $1.4^{\circ} \mathrm{C}$ for 2025 and 1.2 to $2.8^{\circ} \mathrm{C}$ for 2050 based on UKMO. The differences among scenarios were $0.4^{\circ} \mathrm{C}$ for 2025 and $1.9^{\circ} \mathrm{C}$ for 2050 for GISS, $0.3^{\circ} \mathrm{C}$ for 2025 and $1.3^{\circ} \mathrm{C}$ for 2050 for MRI, and $0.2^{\circ} \mathrm{C}$ for 2025 and $0.8^{\circ} \mathrm{C}$ for 2050 for UKMO.

\subsection{Soybean yield projections}

\subsubsection{Rainfed and irrigated soybean yield for 1923 to 2008}

The CSM-CROPGRO-Soybean model was used to simulate soybean growth, development, and yield for 6 cultivars (i.e. DP5634RR, DP5915RR, AG6702, AGS758RR, DP7220RR, and S80-P2) for irrigated and rainfed conditions. Planting dates for the reference years (1923-2008) were May 5, May 15, May 25, and June 5 (Table 2). For rainfed conditions, the number of days to maturity was 1 to $4 \mathrm{~d}$ fewer than for irrigated conditions, but the number of days to maturity of cultivar DP5915RR planted on May 5 and May 15 was the same for both rainfed and irrigated conditions. For later planted soybean, the number of days to maturity was about 15 to $23 \mathrm{~d}$ fewer than for the 
Table 2. Simulated number of days from planting to maturity and grain yield for 6 soybean cultivars (see Table 1) as a function of planting date, for rainfed (R) and irrigated (I) conditions, for 1923 through 2008 (reference years) using observed weather data

\begin{tabular}{|c|c|c|c|c|c|c|c|c|}
\hline \multirow{2}{*}{ Cultivar } & \multicolumn{8}{|c|}{ Planting date } \\
\hline & 5 May (R) & 5 May (I) & 15 May (R) & 15 May (I) & 25 May (R) & 25 May (I) & 5 June (R) & 5 June (I) \\
\hline \multicolumn{9}{|c|}{ No. of days from planting to maturity } \\
\hline DP5634RR & 135 & 137 & 130 & 131 & 125 & 127 & 120 & 122 \\
\hline DP5915RR & 141 & 141 & 136 & 136 & 131 & 132 & 126 & 127 \\
\hline AG6702 & 155 & 156 & 149 & 151 & 144 & 145 & 138 & 140 \\
\hline AGS758RR & 157 & 160 & 150 & 153 & 144 & 147 & 137 & 140 \\
\hline DP7220RR & 155 & 157 & 148 & 151 & 142 & 144 & 135 & 138 \\
\hline $\mathrm{S} 80-\mathrm{P} 2$ & 163 & 167 & 155 & 159 & 148 & 152 & 140 & 144 \\
\hline \multicolumn{9}{|c|}{ Yield (kg ha $\left.{ }^{-1}\right)$} \\
\hline DP5634RR & 1269 & 3060 & 1285 & 2997 & 1278 & 2929 & 1256 & 2855 \\
\hline DP5915RR & 1461 & 3534 & 1480 & 3487 & 1497 & 3435 & 1458 & 3369 \\
\hline AG6702 & 1424 & 3595 & 1434 & 3544 & 1417 & 3481 & 1376 & 3384 \\
\hline AGS758RR & 1365 & 3632 & 1361 & 3506 & 1345 & 3358 & 1305 & 3180 \\
\hline DP7220RR & 1448 & 3669 & 1423 & 3525 & 1382 & 3369 & 1339 & 3185 \\
\hline S80-P2 & 1366 & 3861 & 1373 & 3766 & 1358 & 3640 & 1332 & 3460 \\
\hline
\end{tabular}

earlier planted soybean under both rainfed and irrigated conditions. Yield for the irrigated conditions was approximately 2.5 times higher than the yield for rainfed conditions, while later planted soybeans had a lower yield than earlier planted soybean for all cultivars under both rainfed and irrigated conditions. However, yield for the cultivars DP5634RR and DP5915RR planted on May 25 was higher than for those planted on May 5 for rainfed conditions.

\subsubsection{Yield projections for rainfed conditions}

The management practices that were used to simulate soybean yield for the climate change projections for 2025 and 2050 projections were the same as for the reference years. As discussed earlier, the historical weather data were modified with the climate change patterns using the outputs of the 3 GCMs coupled with the 6 SRES scenarios resulting in a total of 18 different climate patterns. Rather than analyzing the absolute soybean yield predictions, our analysis was based on the differences between the soybean simulations for the reference years and those for 2025 and 2050 projections based on each of the 18 climate patterns. In general, the number of days to maturity for all cultivars decreased compared to the reference years because of the increase in temperature, while yield increased due to the increase in precipitation and $\mathrm{CO}_{2}$ concentration for 2025 and 2050 projections. However, the change in the number of days to maturity and yield varied by planting date, cultivar, GCM, scenario, and projection year.

Based on GISS, the decrease in the number of days to maturity was larger for earlier planted com- pared to later planted soybean (Fig. S5 in the Supplement at www.int-res.com/articles/suppl/c063 p073_supp.pdf). The higher the predicted increase in the monthly mean temperature among the 6 SRES scenarios (Fig. 2), the larger the predicted decrease in the number of days to maturity for the 2025 projections. As expected, the decrease in the number of days to maturity and differences among the scenarios was larger for the 2050 projections than for the 2025 projections (Fig. S5). For the 2025 projections, the number of days to maturity for the cultivar DP5634RR by ca. $-1.5 \mathrm{~d}$ when planted on May 5, but only $-0.8 \mathrm{~d}$ when planted on June 5 ; the cultivars DP5915RR changed and AG6702 showed the similar response and the change ranged from -1 to $-1.8 \mathrm{~d}$. However, the cultivars AGS758RR, DP7220RR, and especially S80-P2 were not sensitive to planting dates and the decrease was -1 to $-1.5 \mathrm{~d}$ for all 4 planting dates. Among the 6 SRES scenarios, the largest decrease was found for the A1T scenario, while the difference among the 6 scenarios was $\sim 0.3 \mathrm{~d}$. For the 2050 projections, cultivars DP5634RR and DP5915RR showed a change of 0 to $-1.2 \mathrm{~d}$ with respect to the number of days to maturity when planted on May 5 and May 15, while the change was from -1 to $-2 \mathrm{~d}$ when planted on May 25 and June 5. The decrease in the number of days to maturity for the other cultivars did not show large difference among the later planting dates, i.e. May 15, May 25, and June 5: changes ranged from -1.7 to $-2.3 \mathrm{~d}$ when planted on May 5 , and from -1 to $-1.8 \mathrm{~d}$ for the other 3 planting dates. The largest decrease was found based on the A1FI, A2, B1, and B2 scenarios, while the differences among the 6 scenarios ranged from 0.2 to $0.7 \mathrm{~d}$. 
Because of the smaller increase in monthly mean temperature based on MRI as compared to GISS, the decrease in the number of days to maturity was also smaller based on MRI (Fig. S6 in the Supplement). Generally, rainfed soybean based on MRI did not show very large differences among the different planting dates and scenarios compared to the GISS projections. Based on MRI, the number of days to maturity decreased approximately -0.4 to $-1 \mathrm{~d}$ for the 2025 projections and approximately -0.3 to $-1.5 \mathrm{~d}$ for the 2050 projections. For the 2025 projections, the cultivars AG6702 and S80-P2 showed a larger decrease of -0.1 to- $0.2 \mathrm{~d}$ when planted on May 25 and June 5 compared to the other planting dates. The differences among the 6 scenarios were $<0.1 \mathrm{~d}$ for the 2025 projections and approximately $0.2 \mathrm{~d}$ for the 2050 projections.

The decrease in the number of days to maturity based on UKMO was intermediate between GISS and MRI, reflecting the fact that UKMO also projected intermediate increases in monthly mean temperature (Fig. 3). There were also a number of detailed differences in the UKMO projections, compared to the other 2 GCMs. Based on UKMO, the change in the number of days to maturity ranged from -0.6 to $-1.4 \mathrm{~d}$ for the 2025 projections and from -0.3 to $-1.7 \mathrm{~d}$ for the 2050 projections. The B2 scenario for the UKMO projection showed the largest decrease in the number of days to maturity compared to the other scenarios.

Based on GISS, the increase in yield was similar for the 6 cultivars, especially for the 2025 projections (Fig. S7). Later planted soybean showed higher increases in yield, especially for cultivars DP5634RR, DP5915RR, and AG6702. Among the 6 scenarios, the increases in yield based on the A1B, A1FI, and
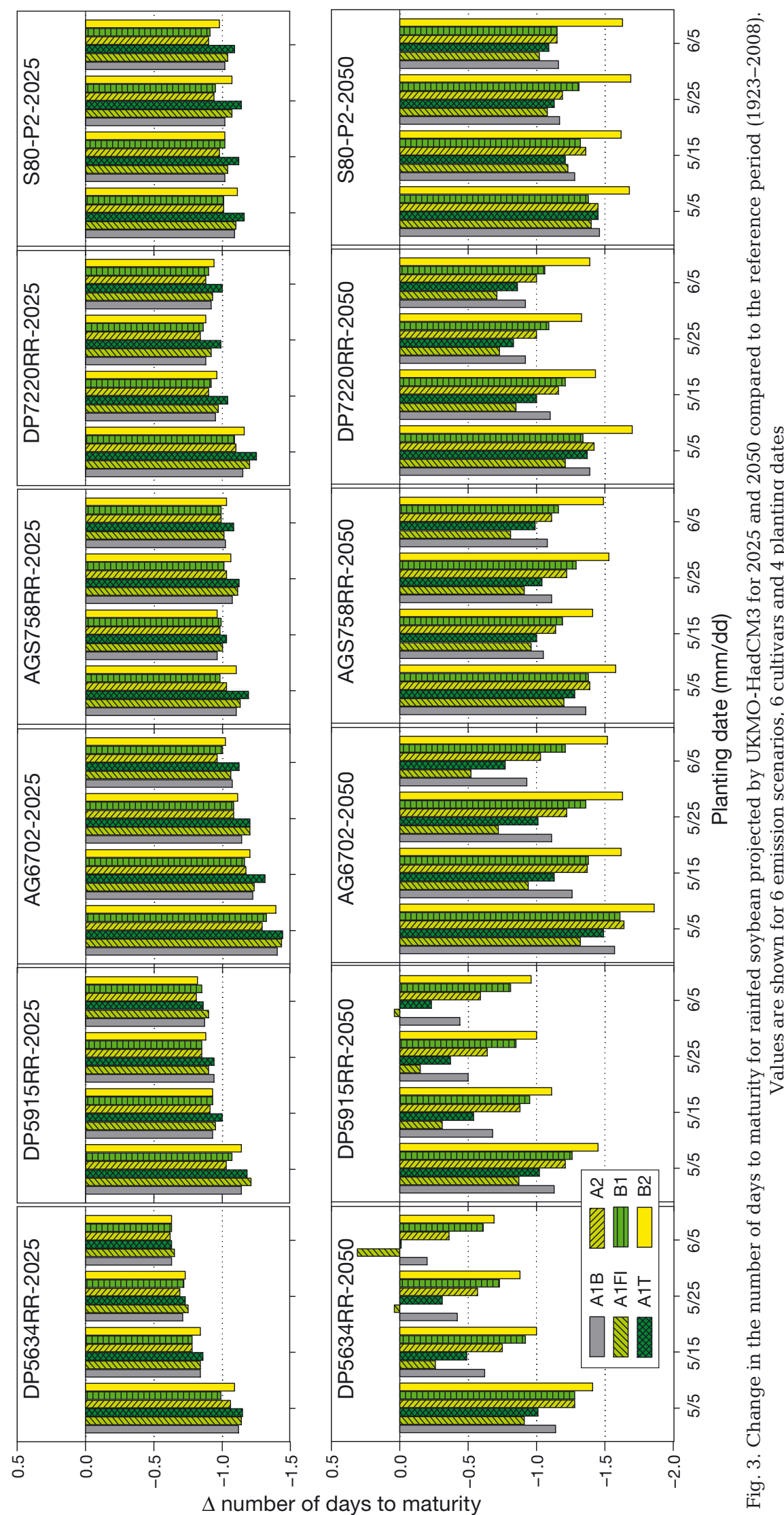


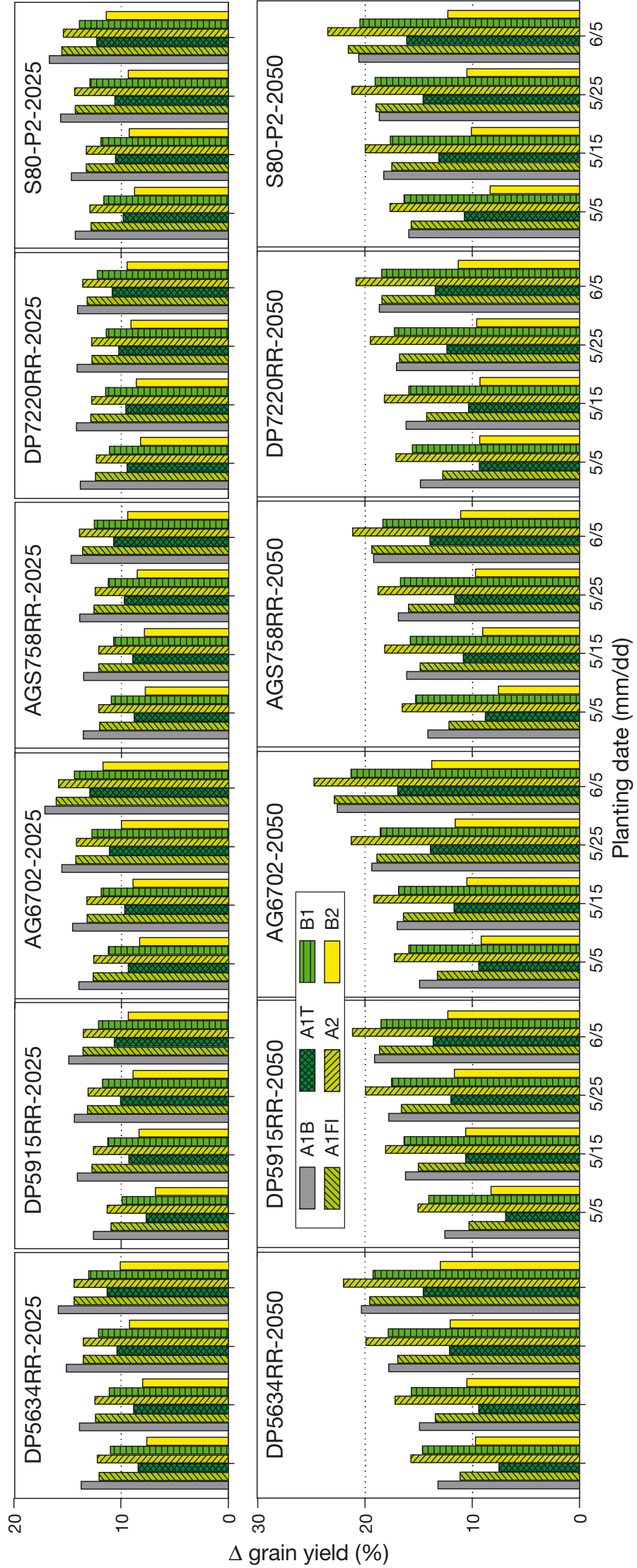

A2 scenarios were higher compared to the others, partly because of relatively higher $\mathrm{CO}_{2}$ concentrations under these scenarios. The increases in yield for the 2050 projections were larger than that for the 2025 projections because of the larger increases in precipitation and $\mathrm{CO}_{2}$ concentration for the 2050 projections. For the 2025 projections, the increase for all cultivars ranged from 12 to $22 \%$. The increase in yield for all cultivars planted on June 5 was approximately $3 \%$ higher than for soybean planted on May 5. The increase in yield based on scenarios A1B, A1FI, and A2 was from 3 to $5 \%$ higher than for the other 3 scenarios. For the 2050 projections, the increase ranged from 17 to $35 \%$ for all cultivars (Fig. S7 in the Supplement). Later planted soybean for the 2050 projections had yields about 2 to $7 \%$ higher compared to earlier planted soybean. The yields based on the $\mathrm{A} 1 \mathrm{~B}, \mathrm{~A} 1 \mathrm{FI}$, and $\mathrm{A} 2$ scenarios were 5 to $8 \%$ higher than for the other 3 scenarios.

Compared to GISS, the increase in rainfed yield based on MRI was lower because of the smaller increase in precipitation but showed a similar trend (Fig. S8). The increase in yield ranged from 11 to $20 \%$ for the 2025 projections and from 16 to $31 \%$ for 2050 projections for all cultivars. Later planted soybean had yields approximately 1 to $6 \%$ higher than earlier planted soybean. The increase in yield based on the A1B, A1FI, and A2 scenarios was 2 to $9 \%$ higher than for the other 3 scenarios.

UKMO generated the smallest increase in precipitation among the $3 \mathrm{GCMs}$, so the increase in rainfed yield was the lowest (Fig. 4). The change in yield ranged from 6 to $17 \%$ for the 2025 projections and from 8 to $25 \%$ for the 2050 projections.

\subsubsection{Yield projections for irrigated condi- tions}

The change in number of days under irrigated conditions showed a trend similar as for the rainfed conditions for all $3 \mathrm{GCMs}$, but the actual values varied. Based on GISS (Fig. S9), the decrease in the number of days was smaller for irrigated than for rainfed soybean for both 2025 and 2050 projections, with the values that varied by no more than $0.3 \mathrm{~d}$. For the 2050 projections, the number of days to 


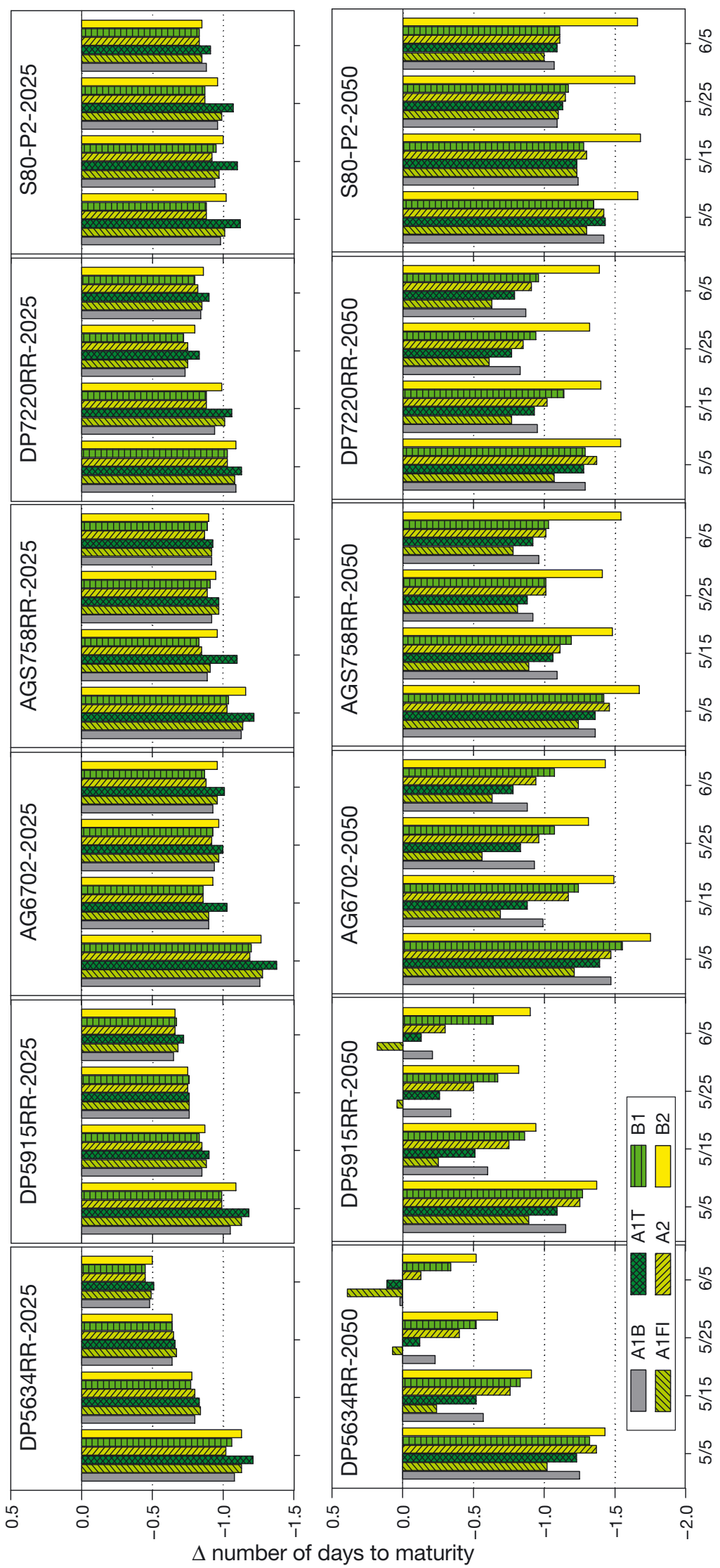

maturity for the cultivar DP5634RR showed an increase of $0.2 \mathrm{~d}$ when planted on June 5 based on scenario A1FI. The changes in the number of days to maturity based on MRI (Fig. S10 in the Supplement) UKMO (Fig. 5) for both 2025 and 2050 projections were comparable to those based on GISS for the 2025 projections.

For irrigated soybean, the increase in grain yield was smaller than that for rainfed conditions for all $3 \mathrm{GCMs}$, since the increase in precipitation had less effect on growing conditions (Figs. S11 \& $\mathrm{S} 10 \mathrm{~b}, \mathrm{c})$. The difference in projected yield increases between irrigated and rainfed conditions was larger for the 2050 than for 2025 based on GISS and MRI; however, UKMO projected similar differences in yield for 2025 and 2050. Based on GISS, the increase in yield for irrigated conditions was 6 to $7 \%$ less than for rainfed conditions for 2025 projections and 8 to $13 \%$ less for 2050 projections (Fig. S11); for MRI, 2 to $6 \%$ less for 2025 projections and 2 to $9 \%$ less for 2050 projections (Fig. S12); and for UKMO, 1 to $5 \%$ less for both 2025 and 2050 projections (Fig. 6). The irrigated soybean showed the largest difference based on GISS because the GISS generated the largest increase in precipitation.

\section{ADAPTATION STRATEGIES}

Based on the analysis of 3 selected GCMs, the change in the number of days to maturity and grain yield for 2025 and 2050 projections compared to the reference years varied by GCM, gas emission scenario, year, variety, and planting date. Various scenarios that were analyzed in this study suggested potential strategies for soybean planting in 2025 and 2050 for adoption by farmers and policy 


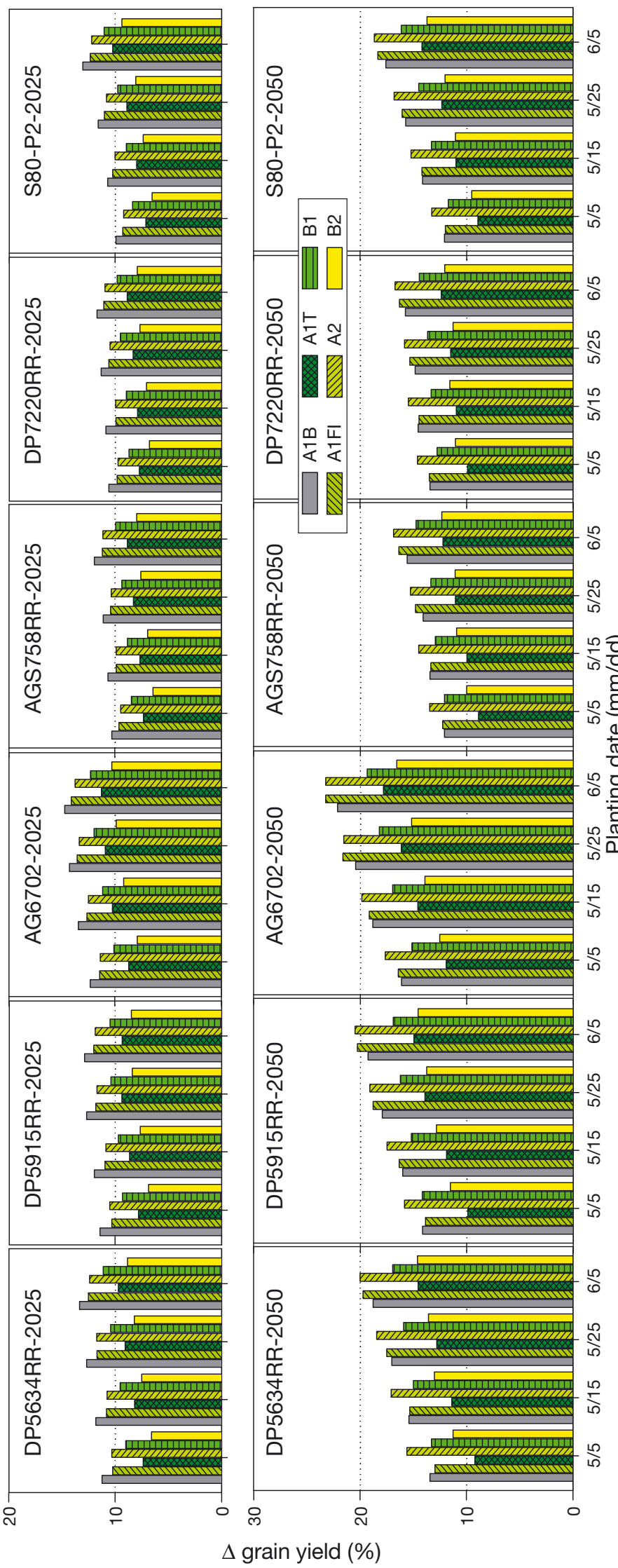

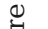

$\stackrel{\Xi}{\Xi}$

$\pi^{\pi}$

कீ

กิ

กิ

ت

임 makers. The use of multiple GCMs and gas emission scenarios was representative of a wide range of conditions, which minimized the uncertainties inherent in the GCMs and gas emission scenarios (Moss et al. 2010).

Adjustment in planting date can minimize the negative effects of changing climate (Carbone et al. 2003) and even take advantage of increasing precipitation (IPCC 2007). This study illustrated that the later planted soybean obtained a higher increase in grain yield than the earlier planted soybean for both rainfed and irrigated conditions from the analysis based on 3 GCMs and 6 scenarios (Table 3). Shifting the planting dates to June 5 might reduce the negative impact from potential heat stress for soybean production for 2025 and 2050 projections.

Grain yield showed an increase in cases where there was a projected increase in precipitation (Table 3). Part of the increase in yield was due to the increase in $\mathrm{CO}_{2}$ concentration for both the 2025 and 2050 projections. For the 2025 projections, the emission scenarios A1B, $\mathrm{A} 1 \mathrm{FI}$, and $\mathrm{A} 2$ that have higher $\mathrm{CO}_{2}$ concentrations also generated a higher increase in the average grain yield compared to the other 3 scenarios based on the 3 selected GCMs. The increased yield for rainfed conditions based on scenarios A1B, A1FI, and A2 was from 11.87 to $16.21 \%$ and the standard deviation among the 3 GCMs ranged from 2.18 to $2.87 \%$. The scenario A1B showed the highest increase in yield $(16.21 \%)$, and with a relatively lower standard deviation among the 3 GCMs (2.29\%), which means that simulations of the $3 \mathrm{GCMs}$ were more stable in response to changes in the emission scenario A1B. Yields of later-planted soybean showed greater increases under all 6 scenarios. The standard deviation decreased when the planting dates were shifted from May 5 to May 25 but was higher for June 5 compared to May 25.

Among the $3 \mathrm{GCMs}$, the increase in rainfed grain yield based on GISS and MRI was greater than UKMO since a larger increase in precipitation was generated for the 2025 projections (Table 3). The standard deviation among the 6 scenarios ranged from 1.92 to $2.01 \%$ for GISS and MRI. However, the precipitation deficit projected by UKMO led to a smaller increase in rainfed yield. The simulations for grain yield based on UKMO were more sensitive to $\mathrm{CO}_{2}$ 
Table 3. Summary statistics for the projected increase in soybean grain yield (\%) in 2025 and 2050, compared to the reference period (1923-2008) (see Table 2). Results are given for 4 planting dates and for (a) rainfed and (b) irrigated conditions, for each of 6 emission scenarios and 3 selected general circulation models (GCMs), i.e. GISS-EH (GISS), MRI-CGCM2.3.2 (MRI), and UKMO-HadCM3 GCM (UKMO). The scenario mean is the average of values projected by the $3 \mathrm{GCMs}$; the GCM mean is the average of values projected for the 6 scenarios

\begin{tabular}{|c|c|c|c|c|c|c|c|c|c|}
\hline & \multirow{2}{*}{$\begin{array}{l}\text { Scenario/ } \\
\text { GCM }\end{array}$} & \multicolumn{2}{|c|}{5 May } & \multicolumn{2}{|c|}{15 May } & \multicolumn{2}{|c|}{25 May } & \multicolumn{2}{|c|}{5 June } \\
\hline & & Mean & $\mathrm{SD}$ & Mean & $\mathrm{SD}$ & Mean & $\mathrm{SD}$ & Mean & $\mathrm{SD}$ \\
\hline \multicolumn{10}{|c|}{ Rainfed } \\
\hline \multirow[t]{9}{*}{2025} & $\mathrm{~A} 1 \mathrm{~B}$ & 16.21 & 2.29 & 16.57 & 2.21 & 17.10 & 2.19 & 18.01 & 2.31 \\
\hline & A1FI & 15.29 & 2.86 & 15.73 & 2.75 & 16.28 & 2.71 & 17.27 & 2.73 \\
\hline & $\mathrm{A} 1 \mathrm{~T}$ & 11.87 & 2.76 & 12.27 & 2.64 & 12.94 & 2.48 & 14.01 & 2.49 \\
\hline & $\mathrm{A} 2$ & 14.98 & 2.48 & 15.27 & 2.33 & 15.77 & 2.27 & 16.71 & 2.23 \\
\hline & B1 & 13.34 & 2.18 & 13.59 & 2.05 & 14.16 & 2.05 & 15.03 & 2.01 \\
\hline & B2 & 11.14 & 2.87 & 11.55 & 2.74 & 12.10 & 2.67 & 13.04 & 2.60 \\
\hline & GISS & 15.98 & 1.92 & 16.30 & 1.93 & 16.94 & 1.95 & 17.94 & 1.95 \\
\hline & MRI & 14.46 & 2.01 & 14.70 & 2.00 & 15.04 & 1.92 & 15.92 & 1.96 \\
\hline & UKMO & 10.97 & 2.18 & 11.49 & 2.15 & 12.18 & 2.10 & 13.18 & 2.02 \\
\hline \multirow[t]{9}{*}{2050} & A1B & 21.11 & 5.96 & 22.59 & 5.41 & 23.92 & 5.31 & 25.97 & 5.18 \\
\hline & A1FI & 20.82 & 7.33 & 22.75 & 6.74 & 24.55 & 6.51 & 26.87 & 6.12 \\
\hline & $\mathrm{A} 1 \mathrm{~T}$ & 15.58 & 5.95 & 17.10 & 5.40 & 18.59 & 5.23 & 20.47 & 5.07 \\
\hline & $\mathrm{A} 2$ & 22.82 & 5.57 & 24.09 & 5.15 & 25.42 & 4.92 & 27.35 & 4.70 \\
\hline & B1 & 20.03 & 4.21 & 20.83 & 4.05 & 21.84 & 3.76 & 23.38 & 3.66 \\
\hline & B2 & 15.15 & 5.72 & 16.23 & 5.66 & 17.10 & 5.69 & 18.72 & 5.78 \\
\hline & GISS & 23.61 & 3.30 & 25.01 & 3.35 & 26.32 & 3.49 & 27.95 & 3.63 \\
\hline & MRI & 21.45 & 3.16 & 22.20 & 3.25 & 23.26 & 3.41 & 25.30 & 3.54 \\
\hline & UKMO & 12.69 & 3.33 & 14.58 & 3.35 & 16.13 & 3.54 & 18.14 & 3.78 \\
\hline \multicolumn{10}{|c|}{ Irrigated } \\
\hline \multirow[t]{9}{*}{2025} & $\mathrm{~A} 1 \mathrm{~B}$ & 11.58 & 0.88 & 12.24 & 0.71 & 12.95 & 0.66 & 13.50 & 0.53 \\
\hline & A1FI & 10.95 & 1.02 & 11.63 & 0.90 & 12.34 & 0.80 & 12.92 & 0.65 \\
\hline & $\mathrm{A} 1 \mathrm{~T}$ & 8.55 & 1.12 & 9.27 & 0.92 & 9.92 & 0.75 & 10.48 & 0.72 \\
\hline & A2 & 10.90 & 1.03 & 11.51 & 0.89 & 12.20 & 0.77 & 12.74 & 0.67 \\
\hline & B1 & 9.62 & 0.93 & 10.23 & 0.79 & 10.89 & 0.65 & 11.38 & 0.59 \\
\hline & B2 & 7.81 & 1.16 & 8.48 & 0.92 & 9.11 & 0.82 & 9.60 & 0.74 \\
\hline & GISS & 9.53 & 1.50 & 10.46 & 1.51 & 11.27 & 1.53 & 11.86 & 1.53 \\
\hline & MRI & 11.06 & 1.41 & 11.46 & 1.42 & 11.96 & 1.48 & 12.37 & 1.48 \\
\hline & UKMO & 9.12 & 1.59 & 9.76 & 1.52 & 10.48 & 1.54 & 11.08 & 1.60 \\
\hline \multirow[t]{9}{*}{2050} & A1B & 15.44 & 2.55 & 16.98 & 2.17 & 18.24 & 1.92 & 19.61 & 1.62 \\
\hline & A1FI & 15.61 & 2.75 & 17.48 & 2.38 & 19.11 & 1.89 & 20.70 & 1.68 \\
\hline & $\mathrm{A} 1 \mathrm{~T}$ & 11.64 & 2.56 & 13.19 & 2.14 & 14.43 & 1.74 & 15.67 & 1.46 \\
\hline & A2 & 16.64 & 2.12 & 18.06 & 1.86 & 19.25 & 1.61 & 20.53 & 1.31 \\
\hline & B1 & 14.43 & 1.62 & 15.57 & 1.34 & 16.48 & 1.20 & 17.43 & 1.00 \\
\hline & B2 & 11.67 & 1.53 & 12.94 & 1.32 & 13.81 & 1.18 & 14.83 & 0.91 \\
\hline & GISS & 13.29 & 2.19 & 14.99 & 2.28 & 16.55 & 2.37 & 17.96 & 2.52 \\
\hline & MRI & 16.73 & 2.36 & 17.81 & 2.45 & 18.61 & 2.58 & 19.53 & 2.76 \\
\hline & UKMM & 12.69 & 1.94 & 14.30 & 1.96 & 15.50 & 2.19 & 16.89 & 2.34 \\
\hline
\end{tabular}

tions. However, the uncertainty of the $3 \mathrm{GCMs}$ projections increased in 2050 compared with 2025, with standard deviations ranging from 3.66 to $7.33 \%$ among the 6 scenarios. Overall, soybean planted on June 5 showed the largest yield increase and the lowest standard deviation, but the lowest standard deviation was for soybean planted on May 25 under the $\mathrm{B} 2$ scenario. The increase in rainfed grain yield based on GISS and MRI for the 2050 projections was 7 to $10 \%$ more than for the 2025 projections. However, the increase in rainfed grain yield based on UKMO was limited by the small increase in precipitation: the increase for the 2050 projections was 2 to $5 \%$ more than for the 2025 projections. For the 3 GCMs, the standard deviation among the 6 scenarios also increased in 2050 compared to 2025 to between 3.16 and $3.78 \%$.

As expected, yield for irrigated conditions was higher than for rainfed conditions. However, the increases in irrigated grain yield for both the 2025 and 2050 projections were smaller than for the rainfed conditions for all GCMs and scenarios because the projected increase in precipitation could offset most of the potential negative effects of higher temperature on rainfed soybean (Table 3). The increase in yield for irrigated conditions based on UKMO was close to that for the rainfed conditions. The standard deviation under irrigated condi-

concentration compared to the other 2 GCMs. Grain yield project by UKMO showed a standard deviation of 2.02 to $2.18 \%$ for 2025 among the 6 scenarios because of a water deficit under rainfed conditions.

The larger increase in precipitation and $\mathrm{CO}_{2}$ concentration caused a greater increase in rainfed grain yield than for the 2050 projections compared to 2025 projections (Table 3). Based on the 6 emissions scenarios the increase for the 2050 projections was approximately 5 to $7 \%$ higher than for the 2025 projec- tions among scenarios and GCMs for both the 2025 and 2050 projections decreased compared to the rainfed conditions, which means that the irrigation can reduce the uncertainty associated with the GCMs and scenarios. This shows that irrigation is a promising adaptation strategy that can be expected to generate higher grain yields under all scenarios for both the 2025 and 2050 projections.

Cultivars responded differently to the changing climate. The cultivars AG6702 and S80-P2 showed a 


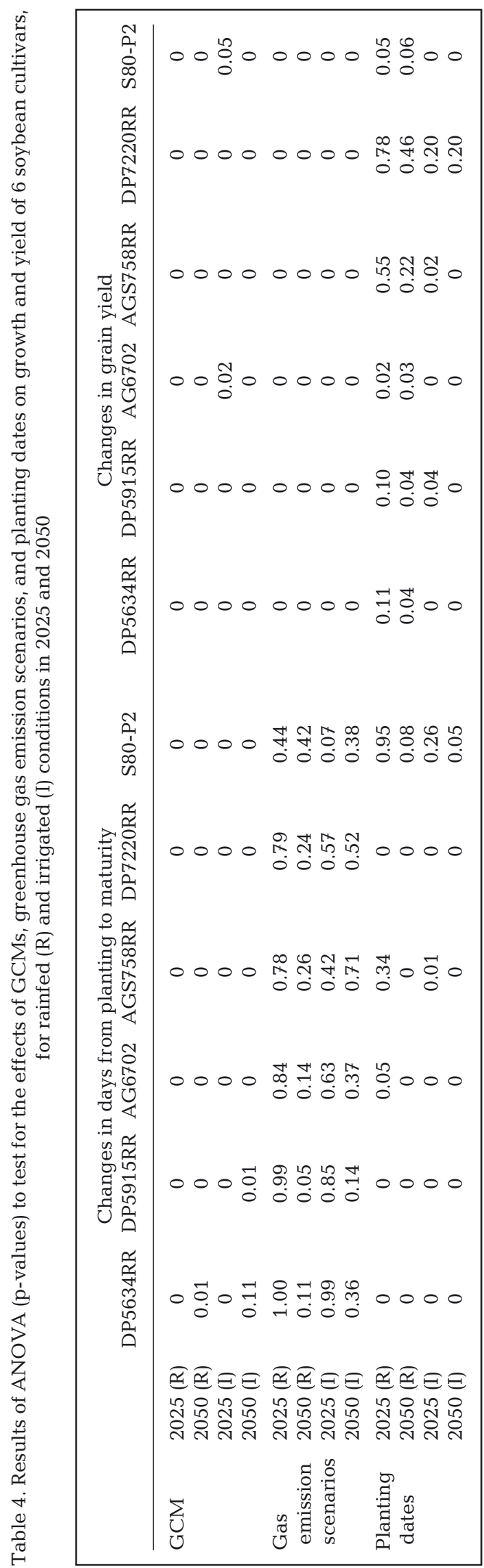

larger increase in yield than the other cultivars when planted on June 5 for rainfed conditions, while the cultivars DP5634RR, DP5915RR and AG6702 showed a larger increase in yield than the other cultivars for irrigated conditions, regardless of planting date. The results of this study suggest that cultivars AG6702 and S80-P2 might be better adapted for rainfed conditions, while the cultivars DP5634RR, DP5915RR, and AG6702 might be better adapted for irrigated conditions.

An ANOVA test was used to statistically analyze the effects of different GCMs, emissions scenarios, and planting dates on the number of days from planting to maturity and grain yield (Table 4). A p-value near zero means there is no difference among the sets of data. Generally, different GCM climate projections did not affect the difference in the number of days from planting to maturity and grain yield. However, the gas emission scenarios had a significant impact on the number of days from planting to maturity, but not on yield. The effect of planting date was mixed. The cultivar S80-P2 showed significant differences with respect to the number of days from planting to maturity for 2025 and 2050 for both rainfed and irrigated conditions, while for yield the effects were only significant for projections for rainfed conditions for 2025 and 2050. The cultivars DP5634RR, DP5951RR and DP7220RR did not show significant differences for the number of days from planting to maturity for the 2025 and 2050 projections for rainfed and irrigated conditions, while some of the differences for yield were significant for these projections. Overall, yield was mainly affected by the changes in planting date, while the number of days from planting to maturity was mainly affected by the different gas emission scenarios due to different projections in temperature for 2025 and 2050.

\section{CONCLUSIONS}

In summary, the number of days to maturity decreased because of the projected increase in temperature for both rainfed and irrigated conditions, while yield increased due to the potential benefit from the projected increase in precipitation and $\mathrm{CO}_{2}$ concentration. Irrigation offset the negative impact of drought for the dry climate pattern projected by UKMO. However, because of the uncertainties associated with the GCMs this study was limited to conducting sensitivity analysis studies and evaluation of methodologies for one location (Mitchell et al. 1999). Future studies should concentrate on additional locations and a more thorough analysis of potential adaptation options. 
Acknowledgements. This work was conducted under the auspices of the Southeast Climate Consortium (SECC) and supported by a partnership with the United States Department of Agriculture-Risk Management Agency (USDARMA), by grants from the US National Oceanic and Atmospheric Administration-Climate Program Office (NOAA-CPO) and USDA National Institute of Food and Agriculture (NIFA) and by State and Federal funds allocated to Georgia Agricultural Experiment Stations Hatch project GEO01179. The dedicated support provided by Kim Evans is gratefully acknowledged.

\section{LITERATURE CITED}

Abuodha PAO (2009) Application and evaluation of shoreline segmentation mapping approaches to assessing response to climate change on the Illawarra Coast, South East Australia. PhD Dissertation, University of Wollongong

Ainsworth EA, Ort DR (2010) How do we improve crop production in a warming world? Plant Physiol 154:526-530

> Ainsworth EA, Davey PA, Bernacchi CJ, Dermody OC and others (2002) A meta-analysis of elevated $\left[\mathrm{CO}_{2}\right]$ effects on soybean (Glycine max) physiology, growth and yield. Glob Change Biol 8:695-709

> Alexandrov VA, Hoogenboom G (2000) Vulnerability and adaptation assessments of agricultural crops under climate change in the Southeastern USA. Theor Appl Climatol 67:45-63

Alley RB, Marotzke J, Nordhaus WD, Overpeck JT and others (2003) Abrupt climate change. Science 299: 2005-2010

Austin PT, Hall AJ (2001) Temperature impacts on development of apple fruits. In: Warrick RA, Kenny GJ, Harman JJ (eds) The effects of climate change and variation in New Zealand: an assessment using the CLIMPACTS system. International Global Change Institute, University of Waikato, Hamilton p 47-55

Backlund P, Schimel D, Janetos A, Hatfield J, Ryan MG, Archer SR, Lettenmaier D (2008) Introduction. In: The effects of climate change on agriculture, land resources, water resources, and biodiversity in the United States. A report by the US Climate Change Science Program and the Subcommittee on Global Change Research. US Department of Agriculture, Washington, DC, p 11-20

Bao Y, Hoogenboom G, McClendon R, Paz JO (2015) Potential adaptation strategies for rainfed soybean production in the southeastern USA under climate change based on the CSM-CROPGRO-Soybean model. J Agric Sci (in press)

> Brekke LD, Dettinger MD, Maurer EP, Anderson M (2008) Significance of model credibility in estimating climate projection distributions for regional hydroclimatological risk assessments. Clim Change 89:371-394

Carbone GJ, Kiechle W, Locke C, Mearns LO, McDaniels L, Downton MW (2003) Response of soybean and sorghum to varying spatial scales of climate change scenarios in the Southeastern United States. Clim Change 60:73-98

Christensen JH, Hewitson B, Busuioc A, Chen A and others (2007) Regional climate projections. In: Solomon S, Qin D, Manning M, Chen Z and others (eds) Climate change 2007: the physical science basis. Contribution of Working Group I to the Fourth Assessment Report of the Intergovernmental Panel on Climate Change. Cambridge University Press, Cambridge, p 867-940
Clark H, Mitchell ND, Newton PCD, Campbell BD (2001) The sensitivity of New Zealand's managed pastures to climate change. In: Warrick RA, Kenny GJ, Harman JJ (eds) The effects of climate change and variation in New Zealand: an assessment using the CLIMPACTS System. International Global Change Institute, University of Waikato, Hamilton, p 65-77

- Coquard J, Duffy PB, Taylor KE, Iorio JP (2004) Present and future surface climate in the western USA as simulated by 15 global climate models. Clim Dyn 23:455-472

Curry RB, Jones JW, Boote KJ, Peart RM, Allen LH Jr (1995) Response of soybeans to predicted climate change in the USA. In: Rosenzweig C, Allen LH Jr, Jones JW, Tsuji GY, Hildebrand P (eds) climate change and agriculture: analysis of potential international impacts. ASA Special Publication Number 59, American Society of Agronomy, Madison, WI, p 163-181

Day JL, Coy AE, Gassett JD (2008) 2008 Soybean, sorghum grain and silage, summer annual forages, and sunflower performance tests. Research Report Number 718, University of Georgia, Athens, GA

> Garcia y Garcia A, Hoogenboom G (2005) Evaluation of an improved daily solar radiation generator for the southeastern USA. Clim Res 29:91-102

Garcia y Garcia A, Guerra LC, Hoogenboom G (2008) Impact of generated solar radiation on simulated crop growth and yield. Ecol Modell 210:312-326

> Garcia y Garcia A, Persson T, Guerra LC, Hoogenboom G (2010) Response of soybean genotypes to different irrigation regimes in a humid region of the southeastern USA. Agric Water Manage 97:981-987

Hall AJ, Kenny GJ, Austin PT, McPherson HG (2001) Changes in kiwifruit phenology with climate. In: Warrick RA, Kenny GJ, Harman JJ (eds) The effects of climate change and variation in New Zealand: an assessment using the CLIMPACTS system. International Global Change Institute, University of Waikato, Hamilton, p 33-46

Hatfield J, Boote K, Fay P, Hahn L and others (2008) Agriculture. In: The effects of climate change on agriculture, land resources, water resources, and biodiversity in the United States. A report by the US Climate Change Science Program and the Subcommittee on Global Change Research. US Department of Agriculture, Washington, DC, p 21-74

> Hoogenboom G, Jones JW, Boote KJ (1992) Modeling growth, development and yield of grain legumes using SOYGRO, PNUTGRO, and BEANGRO: a review. Trans ASAE 35:2043-2056

Hoogenboom G, Jones JW, Wilkens PW, Porter $\mathrm{CH}$ and others (2004) Decision Support System for Agrotechnology Transfer (DSSAT) Version 4.0 [CD-ROM]. University of Hawaii, Honolulu, HI

Hoogenboom G, Jones JW, Wilkens PW, Porter CH and others (2011) Decision Support System for Agrotechnology Transfer (DSSAT) Version 45 [CD-ROM]. University of Hawaii, Honolulu, HI

Hoogenboom G, Jones JW, Traore PCS, Boote KJ (2012). Experiments and data for model evaluation and application. In: Kihara J, Fatondji D, Jones JW, Hoogenboom G, Tabo R, Bationo A (eds) Improving soil fertility recommendations in Africa using the Decision Support Systems for Agrotechnology Transfer (DSSAT). Springer, Dordrecht, p 9-18

Hulme M, Wigley TML, Barrow EM, Raper SCB, Centella A, Smith S, Chipanshi AC (2000) Using a climate scenario 
generator for vulnerability and adaptation assessment: MAGICC and SCENGEN Version 2.4 workbook. Climatic Research Unit, Norwich

Hunt LA, Boote KJ (1998) Data for model operation, calibration, and evaluation. In: Tsuji GY, Hoogenboom G, Thornton PK (eds) Understanding options for agricultural production. Kluwer Academic Publishers, Dordrecht, p 9-39

IPCC (Intergovernmental Panel on Climate Change) (2007) Climate change 2007: the physical science basis. Contribution of Working Group I to the Fourth Assessment Report of the Intergovernmental Panel on Climate Change. Cambridge University Press, Cambridge

IPCC (2013) Summary for policymakers. In: Climate change 2013: the physical science basis. Contribution of Working Group I to the Fifth Assessment Report of the Intergovernmental Panel on Climate Change. Cambridge University Press, Cambridge

Jamieson PD, Cloughley CG (2001) Impacts of climate change on wheat production. In: Warrick RA, Kenny GJ, Harman JJ (eds) The effects of climate change and variation in New Zealand: an assessment using the CLIMPACTS system. International Global Change Institute, University of Waikato, Hamilton, p 57-63

Jones JW, Hoogenboom G, Porter CH, Boote KJ and others (2003) The DSSAT cropping system model. Eur J Agron 18:235-265

Kenny GJ, Warrick RA, Mitchell ND, Mullan AB, Salinger MJ (1995) CLIMPACTS: an integrated model for assessment of the effects of climate change on the New Zealand environment. J Biogeogr 22:883-895

Kenny GJ, Warrick RA, Campbell BD, Sims GC and others (2000) Investigating climate change impacts and thresholds: an application of the CLIMPACTS integrated assessment model for New Zealand agriculture. Clim Change 46:91-113

Kenny GJ, Harman JJ, Warrick RA (2001a) Introduction: The CLIMPACTS programme and method. In: Warrick RA, Kenny GJ, Harman JJ (eds) The effects of climate change and variation in New Zealand: an assessment using the CLIMPACTS system. International Global Change Institute, University of Waikato, Hamilton, p 1-10

Kenny GJ, Ye W, Flux T, Warrick RA (2001b) Climate variations and New Zealand agriculture: the CLIMPACTS system and issues of spatial and temporal scale. Environ Int 27:189-194

Kenny GJ, Harman JJ, Flux TL, Warrick RA, Ye W (2001c) The impact of climate change on regional resources: a case study for Canterbury and Waikato Regions. In: Warrick RA, Kenny GJ, Harman JJ (eds) The effects of climate change and variation in New Zealand: an assessment using the CLIMPACTS system. International Global Change Institute, University of Waikato, Hamilton, p 85-98

Mavromatis T, Boote KJ, Jones JW, Irmak A, Shinde D, Hoogenboom G (2001) Developing genetic coefficients for crop simulation models with data from crop performance trials. Crop Sci 41:40-51

> Mavromatis T, Boote KJ, Jones JW, Wilkerson GG, Hoogenboom G (2002) Repeatability of model genetic coefficients derived from soybean performance trials across different states. Crop Sci 42:76-89

> Mearns LO, Giorgi F, McDaniel L, Shields C (2003) Climate scenarios for the southeastern US based on GCM and regional model simulations. Clim Change 60:7-35
Meehl GA, Stochker TF, Collines WD, Friedlingstein P and others (2007) Global climate projections. In: Solomon S, Din D, Manning M, Chen Z and others (eds) Climate change 2007: the physical science basis. Contribution of Working Group I to the Fourth Assessments Report of the Intergovernmental Panel on Climate Change. Cambridge University Press, Cambridge, p 748-845

> Mitchell JFB, Johns TC, Eagles M, Ingram WJ, Davis RA (1999) Towards the construction of climate change scenarios. Clim Change 41:547-581

Moss RH, Edmonds JA, Hibbard KA, Manning MR and others (2010) The next generation of scenarios for climate change research and assessment. Nature 463:747-756

Nakicenovic N, Swart R (eds) (2000) Special report on emissions scenarios. A special report of Working Group III of the Intergovernmental Panel on Climate Change. Cambridge University Press, Cambridge

Nijbroek R, Hoogenboom G, Jones JW (2003) Optimal irrigation strategy for a spatially variable soybean field: a modeling approach. Agric Syst 76:359-377

Parshotam A, Tate KR (2001) The impacts of climate change on soils and land systems in New Zealand. In: Warrick RA, Kenny GJ, Harman JJ (eds) The effects of climate change and variation in New Zealand: an assessment using the CLIMPACTS system. International Global Change Institute, University of Waikato, Hamilton, p 79-84

Perkins HF, Hook JE, Barbour NW (1986) Soil characteristics of selected areas of the Coastal Plain Experiment Station and ABAC Research Farm. Research Bulletin 346. The University of Georgia Agricultural Experiment Stations, Athens, GA

Pierce DW, Barnett TP, Santer BD, Gleckler PJ (2009) Selecting global climate models for regional climate change studies. Proc Natl Acad Sci USA 106:8441-8446

Rivington M, Matthews KB, Bellocchi G, Buchan K (2006) Evaluating uncertainty introduced to process-based simulation model estimates by alternative sources of meteorological data. Agric Syst 88:451-471

Rivington M, Miller D, Matthews KB, Russell G, Bellocchi G, Buchan K (2008) Evaluating regional climate model estimates against site-specific observed data in the UK. Clim Change 88:157-185

Rosenzweig C, Casassa G, Karoly DJ, Imeson A and others (2007) Assessment of observed changes and responses in natural and managed systems. In: Parry ML, Canziani OF, Palutikof JP, van der Linden PJ, Hanson CE (eds) Climate change 2007: impacts, adaptation and vulnerability. Contribution of Working Group II to the Fourth Assessment Report of the Intergovernmental Panel on Climate Change. Cambridge University Press, Cambridge, p 79-131

Sakurai G, Lizumi T, Yokozawa M (2011) Varying temporal and spatial effects of climate on maize and soybean affect yield prediction. Clim Res 49:143-154

- Salazar MR, Hook JE, Garcia y Garcia A, Paz JO, Chaves B, Hoogenboom G (2012) Estimating irrigation water use for maize in the Southeastern USA: a modeling approach. Agric Water Manag 107:104-111

Seager R, Ting M, Held I, Kushnir Y and others (2007) Model projections of an imminent transition to a more arid climate in southwestern North. Science 316:1181-1184

Semenov MA, Barrow EM (1997) Use of a stochastic weather generator in the development of climate change scenarios. Clim Change 35:397-414

Storey LP (2009) Effect of climate and land use change on 
invasive species: a case study of Tradescantia fluminensis (Vell.) in New Zealand. PhD Dissertation, University of Waikato, Hamilton

Trenberth KE (2011) Changes in precipitation with climate change. Clim Res 47:123-138

Tsvetsinskaya EA, Mearns LO, Mavromatis T, Gao W, McDaniels L, Downton MW (2003) The effect of spatial scale of climatic change scenarios on simulated maize, winter wheat, and rice production in the southeastern United States. Clim Change 60:37-71

Warrick RA (2007) SimCLIM: recent developments of an integrated model for multi-scale, risk-based assessments of climate change impacts and adaptation. The 2007 ANZSEE Conference Papers, Australia-New Zealand Society for Ecological Economics. www.anzsee.org/2007 conference/conference_papers.asp (accessed on 21 Jan 2015)

Warrick RA (2009) From CLIMPACTS to SimCLIM: devel-

Editorial responsibility: Mikhail Semenov,

Harpenden, UK opment of an integrated assessment model system. In: Knight CG, Jager J (eds) Integrated regional assessment of global climate change. Cambridge University Press, Cambridge, p 280-311

Warrick RA, Kenny GJ, Sims GC, Erichsen NJ, Ahmad QK, Mirza MQ (1996) Integrated model systems for national assessments of the effects of climate change: applications in New Zealand and Bangladesh. Water Air Soil Pollut 92:215-227

Warrick RA, Ye W, Kouwenhoven P, Hay JE, Cheatham C (2005) New development of the SimCLIM model for simulating adaptation to risks arising from climate variability and change. In: Zerger A, Argent RM (eds) Proc MODSIM05 International Congress on Modelling and Simulation. Advances and applications for management and decision making. Melbourne, 12-15 Dec 2005. Modelling and Simulation Society of Australia and New Zealand, Perth, p 551-558

Submitted: May 26, 2014; Accepted: December 17, 2014 Proofs received from author(s): March 14, 2015 